\title{
Levande samtal om den odödliga Henrietta: Biografin som stöd för reflekterande diskussion och lärande
}

\author{
Erika Wall \\ Mittuniversitetet
}

\begin{abstract}
Här diskuteras om och hur en biografi kan bidra till reflekterande diskussioner och kritiskt tänkande i grundutbildning om etik. Den biografi som fokuseras är "Den odödliga Henrietta Lacks" av Rebecca Skloot. Bokens användning redovisas och diskuteras med fokus på det litteraturseminarium som ingick i kursen. Slutsatsen, baserad på såväl lärar- som studentperspektiv, är att biografin fungerar väl som grund för reflekterande diskussioner. Genom att skildra komplexa och känslomässigt starka situationer skapar berättelsen om Henrietta Lacks engagemang och bidrar till en mer komplex förståelse av olika perspektiv på etik och moral kopplade till vård och medicinsk forskning.
\end{abstract}

Nyckelord: etik, kritiskt tänkande, litteratursamtal

\section{LITTERATURSAMTAL FÖR REFLEKTION OCH KRITISKT TÄNKANDE}

Som kursansvarig och undervisande lärare i en etikkurs för studenter i rehabiliteringsvetenskap har det synliggjorts att de teoretiska perspektiven blir allt för abstrakta för att fullt ut greppa och koppla till specifika händelser i samtal om etiska problem. De teoretiska begreppen inom området tycks vara svåra för studenterna att knyta till reella frågor och situationer. För att bidra till ökad analytisk förmåga och kritiskt tänkande vad gäller etik har vi introducerat en biografi som obligatorisk kurslitteratur. Biografin används som underlag för reflekterande samtal om etik. Erfarenheterna från arbetet med denna bok och de aktiviteter som kopplats till denna kommer att diskuteras här.

Föreliggande reflektion ansluter till den vetenskapliga diskursen om litteraturens roll för att främja reflekterande diskussion och förmåga till kritiskt tänkande (Dimaano \& Spigner, 20I7; Lewenstein, 2007; Lie et al., 2002; Nisbet \& Fahy, 2013; Walton, 2014), det vill säga förmågan "att kunna se, artikulera, problematisera och laborera med sina synsätt" (Wolrath Söderberg, 20I6, s. 47). I biografier, fiktion, populärvetenskap och annan icke-traditionell kurslitteratur kan komplexa vetenskapliga frågor göras begripliga genom kontextualisering och överföring till konkreta och vardagliga sammanhang (Dimaano \& Spigner, 2017; Lewenstein, 2007; Lie et al., 2002; Nisbet \& Fahy, 20I3; Walton, 20I4). Detta kan relateras till synen på litteratur som en ram inom vilken läsaren skapar värdeladdade bilder av människan vilka påverkar läsarens uppfattningar om normer och värderingar (Eckart \& Fjordevik, 20I5). Gemensam läsning av sådana texter kan hjälpa studenterna att utveckla etiskt grundade ståndpunkter och empatisk förmåga (Black et al., 20I2), träna kritiskt tänkande (Clouser, I990; Weed, I995), koppla ihop abstrakta vetenskapliga frågor och praktik samt stimulera studentaktivitet och samarbete (Hunt et al., 20I9).

Författarkontakt: erika.wall@miun.se

Artiklar och reflektioner är kollegialt granskade. Övriga bidragstyper granskas av redaktionen. Se https://hogreutbildning.se ISSN 2000-7558

(C)2021 Erika Wall. This is an Open Access article distributed under the terms of the Creative Commons Attribution-NonCommercial 4.0 International License (https://creativecommons.org/licenses/by-nc/4.0/), allowing third parties to share their work (copy, distribute, transmit) and to adapt it, under the condition that the authors are given credit, that the work is not used for commercial purposes, and that in the event of reuse or distribution, the terms of this license are made clear

Citation: Wall, E. (2021). "Levande samtal om den odödliga Henrietta: Biografin som stöd för reflekterande diskussion och lärande», Högre utbildning, 11(2), 46-57. https://doi.org/10.23865/hu.v11.2971 
I den här texten diskuteras en specifik undervisningssituation, där en biografi användes som underlag för reflekterande samtal om etiska frågeställningar. Att på detta sätt lyfta ett konkret exempel för reflektion kring undervisning knyter an till de idéer om "det akademiska lärarskapet" (Silén \& Bolander Laksov, 2013), där det vetenskapliga skrivandet om undervisningspraktik lyfts som ett uttryck för utveckling av högre utbildning genom synliggörande av personliga erfarenheter (Fjellström \& Wester, 2019; Ödman, 2007). Förhoppningen är att föreliggande reflektion ska bidra till sådan utveckling.

Mot denna bakgrund är syftet här att diskutera om, och hur, användningen av en biografi kan bidra till reflekterande diskussioner inom ramen för samhällsvetenskaplig grundutbildning.

\section{DEN ODÖDLIGA HENRIETTA LACKS}

"Den odödliga Henrietta Lacks" av Rebecca Skloot (svensk översättning 20I2), gavs ut i USA 2010 under titeln The Immortal Life of Henrietta Lacks (Skloot, 20IO). Boken är skriven av journalisten Rebecca Skloot som, med utgångspunkt i litteraturstudier, arkivsökningar och intervjuer med efterlevande, återger den gripande livsberättelsen om Henrietta Lacks.

Henrietta var en fattig afroamerikansk kvinna född 1920 som avled I95I efter svår livmoderhalscancer. Under sitt sista levnadsår kom hon att bli återkommande patient på Johns Hopkinssjukhuset i Baltimore där hon undersöktes och fick behandling för den cancer hon drabbats av. I samband med provtagning togs, utan medgivande från Henrietta eller hennes familj, cellprover för forskning. Dessa celler kom att kallas för HeLa-celler (efter initialerna i hennes namn) och var de första mänskliga celler vilka fungerat väl för cellodling. HeLa-cellerna har haft mycket stor betydelse för medicinsk forskning. Bland de exempel som vanligen lyfts fram för att visa på HeLa-cellernas avgörande betydelse nämns att forskning baserad på dessa har legat till grund för läkemedel mot herpes, leukemi, blödarsjuka och Parkinsons sjukdom. Även utveckling av provrörsbefruktning (IVF) och framtagandet av vaccin mot polio - vilket belönades med Nobelpris - var direkt avhängigt tillgången till HeLa-celler.

Biografin är inte en beskrivning av ett patientfall, utan dokumenterar Henriettas livsberättelse med fokus på hennes möte med hälso- och sjukvårdssystemet och hur denna process påverkat hennes familj och efterlevande. I sin bok sammanför Skloot berättelsen om det sammanhang i vilket Henrietta levde med berättelsen om hur forskare använde HeLa-celler för att uppnå framstående medicinska framsteg samt de efterlevandes strävan efter upprättelse för hanteringen av HeLa-cellerna.

Biografin över Henrietta Lacks används idag som obligatorisk kurslitteratur på flera håll. I Sverige finns ingen möjlighet att söka i samtliga kursplaner men jag har kunnat se att biografin, förutom i min egen kurs i rehabiliteringsvetenskap (Etiska perspektiv på hälsa och rehabilitering i arbetslivet, 7,5 hp), har använts i en universitetsövergripande doktorandkurs i etik på Mittuniversitetet (Ethics in social science, 7,5 hp), i medicin vid Örebro universitet (Tumörpatologi, avancerad nivå, Is hp) och i audologi vid Karolinska Institutet, Stockholm (Professionell utveckling II, grundläggande nivå, I, 5 hp). I USA, det land som utgör centrum för berättelsen, har biografin inkluderats som kurslitteratur på fler än I5O universitet (Hunt et al., 2020).

En rad studier har undersökt hur biografin om Henrietta Lacks kan användas för bokklubbsliknande samtal. I en utbildning för farmaceuter (se Black et al., 20I2) genomfördes strukturerade litteratursamtal kring boken utifrån övergripande frågor som till exempel: Skulle 
de situationer som beskrivs i boken kunna uppstå idag? Har medicinsk kunskap förändrats från 1950-talet till idag? Vad är informerat samtycke? Hur skulle du resonera om du eller en familjemedlem ombads om samtycke vad gäller att ta vävnad för forskning? Vidare skulle studenterna diskutera frågor som berörde deras roll som blivande apotekare, till exempel om de blev förvånade över att apotekare inte alls nämns i boken. I en kurs i medicinsk etik byggde upplägget på en kombination av strukturerad läsning med uppföljning av i vilken mån studenterna tagit till sig av (fakta)innehåll ur specifika delar av biografin. Vid varje samling genomfördes inledningsvis ett kunskapstest för att säkerställa att studenterna hade med sig likvärdig kunskap inför de följande diskussionerna som fokuserade på teman som ekonomiska drivkrafter i medicinsk forskning och (frivilliga/ofrivilliga) donationer av celler, vävnader och organ (se vidare i Malcom, 20I8, s. 603-604). Ett liknande upplägg hade en kurs i folkhälsovetenskap (se Dimaano \& Spigner, 20I7). Här utvärderades studenternas kunskaper om betydelsen av socioekonomisk status, etnicitet och kön för skillnader i hälsa och tillgång till vård och vårdkvalitet före och efter litteraturdiskussionerna. Det blev tydligt att läsningen hjälpte studenterna att kontextualisera hur hälsa kopplas samman med sociala och ekonomiska levnadsförhållanden och bidrog till en djupare förståelse (Dimaano \& Spigner, 2017).

Liknande studier av att använda "Den odödliga Henrietta Lacks" inom amerikansk högre utbildning finns inom hälsovetenskap (Virtue et al., 20I8), folkhälsovetenskap (Dimaano \& Spigner, 20I7), hälsoadministration (Bridges \& Hanson, 20I2), medicin och farmaceutik (Van Winkle et al., 20I2; Black et al., 20I2), omvårdnad (Bridges \& Hanson, 20I2; Hunt et al., 2020; Lewis \& Estis, 2020; Malcom, 2018) och biologi (Walton, 20I4). Etiska perspektiv har fokuserats i flera studier (Black et al., 20I2; Bridges \& Hanson, 20I2; Dimaano \& Spigner, 20I7; Malcom, 2018; Walton, 20I4; Virtue et al. 2018). Samtliga studier visar positiva effekter på studenternas lärande. Studenterna tränas i att diskutera komplexa etiska dilemman (Malcom, 20I8), belysa betydelsen av kultur, socioekonomisk status och integritet (Hunt et al., 2020) och att förstå sambandet mellan socioekonomiska skillnader och etik (Virtue et al., 20I8). Biografin ger stöd för fördjupade diskussioner specifikt kring etik och hälsa (Black et al., 20ı2; Bridges \& Hanson, 20I2; Malcom, 20I8) och synliggör ämnets komplexitet genom att knyta ihop frågor om informerat samtycke, betydelsen av klass, kön och etnicitet för hälsa och tillgång till vård, ekonomiska perspektiv på medicinsk forskning, vetenskaplig utveckling och betydelsen av makt i relationen mellan vårdgivare och patient samt frågor som rör personlig integritet (Nisbet $\&$ Fahy, 2013).

\section{ETISKA PERSPEKTIV PÅ HÄLSA OCH REHABILITERING I ARBETSLIVET}

Här används ett konkret undervisningsexempel hämtat från kursen Etiska perspektiv på hälsa och rehabilitering i arbetslivet (Etikkursen). Kursen ges inom ramen för Programmet för hälsa och rehabilitering i arbetslivet, ett kandidatprogram vid Mittuniversitetet. Etikkursen omfattar 7,5 högskolepoäng och ges på helfart under vårterminens sista fem veckor. Vårterminen 2020 genomfördes kursen helt på distans. Kursen har utformats av kursansvarig (författare till föreliggande text) och är uppbyggd i enlighet med Biggs modell för konstruktiv länkning (Biggs \& Tang, 20II; Biggs, I999, 2003) vilket innebär ett upplägg som syftar till att ge tydliga kopplingar mellan lärandemål, läraktiviteter, examinationer och bedömning. Denna länkning skapar ett sammanhang för studenten och ger förutsättningar för lärande (Biggs \& Tang, 20II). I Etikkursen var innehållet vid genomförandet detta år uppdelat i tre delar där de undervisningsmoment 
och examinationer som ingår knyter an mot specifika lärandemål. Inledningsvis fokuserades teoretiska perspektiv på etik följt av kursens andra del där teorier applicerades på fiktiva situationer genom ett grupparbete. Dessa båda första delar av kursen relaterade till kurslitteratur av Edlund (20IO) respektive Henriksen och Vetlesen (2013). Kursens avslutande del innehöll en fördjupad analys kring etiska och moraliska perspektiv, som detta år relaterades för första gången till biografin över Henrietta Lacks. För att uppmuntra till aktivitet hos studenterna (Biggs, 2003) ingick i kursens avslutande del det litteraturseminarium som fokuseras i föreliggande reflektion. Kursen avslutades med en promemoria som skrevs enskilt. Vid genomförande av kursen undervisade kursansvarig universitetslektor (författare till föreliggande reflektion) tillsammans med en adjunkt.

\section{Litteraturseminarium}

Det obligatoriska litteraturseminariet syftade till att ge studenterna möjlighet att reflektera över etiska och moraliska perspektiv och hur dessa framkommer i "Den odödliga Henrietta Lacks". Seminariet bestod av två delar. Den första delen avsåg att sätta boken i ett sammanhang genom att lyfta innehållet i biografin på ett bokklubbsliknande sätt vilket går att jämföra med de upplägg som beskrivits i tidigare studier som redogör för användningen av biografin i undervisning om etik (Black et al., 20I2; Dimaano \& Spigner, 2017; Malcom, 20I8). Med avstamp i dessa tidigare studier, som också visat att arbete med icke-traditionell kurslitteratur varit framgångsrikt vad gäller att främja studenters förmåga till kritiskt tänkande (Clouser, 1990; Weed, 1995) avsåg den andra delen av seminariet att ge förutsättningar för reflekterande diskussioner kring etik baserat på de teoretiska kunskaper studenterna inhämtat under de första delarna av kursen och genom att knyta an mot de berättelser som vävs samman i Skloots biografi. Upplägget uppmuntrade till synliggörande av olika perspektiv och reflektion kring dessa och studenterna påmindes om att det således inte handlade om att ta ställning till vilka tolkningar som var mer eller mindre rimliga. Detta sätt att i seminarieform lyfta varierande perspektiv snarare än att göra bedömningar har framhållits som ett fungerande arbetssätt för att stärka förmåga till kritiskt tänkande och "perspektivisering" (Wolrath Söderberg, 2016).

Inför användningen av biografin över Henrietta Lacks som kurslitteratur fanns en farhåga om att studenterna skulle ha svårt att hinna läsa och förbereda sig inför seminariet och den efterföljande analysuppgift som genomfördes enskilt och som baserades på den individuella läsningen och seminariediskussionen. En utmaning som vi såg vad gäller användningen av biografin relaterades till att alla studenter inte kan förväntas vara vana läsare av icke-traditionell kurslitteratur och att biografin också är förhållandevis omfattande (knappt 400 sidor). Efter diskussion med lärosätets Forsknings- och utbildningsstöd om syftet med momentet konstaterades att målet var att studenterna skulle ta del av Henriettas livsöde och kunna identifiera och återge olika centrala scener i boken vilka belyser komplexiteten i etiska spörsmål. Utifrån detta bestämde vi att studenterna kunde välja mellan att läsa och att lyssna på biografin. Detta var mycket uppskattat av studenterna och i något fall lyftes också detta fram i samtal mellan student och lärare som en möjlighet att på lika villkor delta i kursen, också som student med läs- och skrivsvårigheter.

Inför seminariet fick studenterna alltså i uppgift att läsa eller lyssna på biografin och att välja ut en scen (en situation eller företeelse) ur boken som upplevdes vara särskilt viktig utifrån etiska perspektiv. De instruktioner för genomförandet av litteraturseminariet som studenterna fick ta del av såg ut så här: 


\section{Erika Wall}

Del I, bokens innehåll (ca 30 minuter)

Diskutera bokens innehåll utifrån följande punkter:

- Vad handlar boken om? Delar ni uppfattning om detta?

- Hur är berättelsen uppbyggd? Vems berättelse berättas? Finns det flera röster?

- I vilken miljö utspelar sig boken? Hur påverkar det berättelsen?

- Hur uppfattar ni personerna i berättelsen? Vad tror ni det är som får er att känna så?

- Finns det något särskilt i boken som ni reagerar (positivt/negativt) på? Vad tror ni det är som får er att känna så?

- Har boken förmedlat några nya insikter?

Del 2, etiska/moraliska perspektiv (ca 30 minuter)

Gå laget runt och presentera vald scen för varandra.

- Vilka etiska/moraliska perspektiv lyfts fram i valda scener?

- På vilka sätt bidrar de scener ni valt till att bära berättelsen?

- Tycker ni att boken har ett budskap i fråga om etik/moral? Vad i så fall? Hur kommer det fram?

Vid seminariet, som genomfördes på distans med stöd av universitetets verktyg för distansundervisning, delades studenterna upp i mindre grupper om tre till fyra personer. Vi lärare deltog inte aktivt under seminariet men turades om att omväxlande gå in i respektive grupprum (break out rooms) för att lyssna på diskussionerna. Lärarna var inte aktiva som samtalspartners. De flesta grupper tog sig an den första delen av seminariet genom att följa instruktionerna både vad gäller innehåll och ordning. Studenterna inledde med att upprepa frågan från instruktionen. Därefter turades de om att återge sin tolkning. För första frågan (Vad handlar boken om?) kunde en sådan tolkning till exempel vara att biografin handlar om Henrietta Lacks levnadsöde, eller att den ger en bakgrund till HeLa-cellerna eller beskriver hur det var att leva som mörkhyad och fattig i USA i mitten av 1900-talet. Slutligen diskuterades likheter och skillnader mellan tolkningar som gjorts för respektive fråga. Dessa avslutande diskussioner kunde vara mer eller mindre omfattande och många gånger gav de associationer till andra aspekter vilket ledde gruppen vidare in i bredare diskussioner. Samtal om etnicitet och villkor för olika befolkningsgrupper i olika kulturella sammanhang och/eller vid olika tidpunkter i historien gav till exempel upphov till diskussioner om den samiska befolkningsgruppens villkor i Sverige.

Den andra delen av seminariet inleddes i de flesta grupper genom att studenterna redovisade respektive scen för att därefter gemensamt diskutera dessa scener utifrån moraliska och etiska perspektiv. Bland de scener som valdes fanns beskrivningen av när Henrietta Lacks genomgår sin första cancerbehandling vilket synliggör bemötandet av henne som svart, fattig och outbildad och där också provtagningen som ligger till grund för HeLa-cellerna görs; återgivningen av den vetenskapliga artikel i vilken Henrietta Lacks namnges och som utgör grunden för upptäckten att det är just hennes celler som använts för utvecklingen av cellinjen HeLa; utdrag ur Henriettas dotters dagboksanteckningar där hon uttrycker en känsla av att hennes mamma och hela familjen fått sina rättigheter kränkta till följd av att cellprover togs från Henrietta utan medgivande - i dagboksanteckningarna står det att "vi utnyttjades genom att ta vårt blod och ljög” (Skloot, 20IO, s. 286). Några studenter valde att fokusera på mer övergripande scener ur biografin där villkoren för mörkhyade människor illustrerades som en bakgrundsbeskrivning till Henriettas specifika situation. Bland dessa exempel fanns beskrivningar av hur det sjukhus där Henrietta fick sin cancerbehandling - vilket var ett av få sjukhus som på tidigt I950-tal överhuvudtaget tog emot mörkhyade patienter (Skloot, 20IO, s. 28) - anklagas för att ha genomfört 
oetisk forskning på mörkhyade unga män vilka bland annat blivit injicerade med syfilis för att möjliggöra studier på sjukdomen (Skloot, 20Io, s. 79-80).

I några grupper valde man att dela upp avsatt seminarietid och gå igenom respektive scen var för sig. Det innebar att en scen presenterades och diskuterades och att denna diskussion avslutades innan nästa student presenterade sin scen och samtalet gick vidare. Oavsett upplägg kom den andra delen av seminariet att knyta an till såväl biografin om Henrietta Lacks som den teoretiska litteraturen på kursen (Edlund, 20IO; Henriksen \& Vetlesen, 20I3). Genom att återknyta till de teorier de arbetat med tidigare under kursen skapades förutsättningar för tolkningar av valda scener utifrån olika perspektiv.

\section{BIOGRAFINS ROLL FÖR DISKUSSION OCH LÄRANDE}

Genom att som lärare gå runt i grupperna och lyssna på samtalen mellan studenterna var det möjligt att följa studenternas arbete. Det var tydligt att deltagarna arbetade strukturerat genom att knyta an olika scener hämtade från "Den odödliga Henrietta Lacks" till de olika teoretiska perspektiv på etik som de arbetat med under första delen av kursen. Studenterna reflekterade över på vilka sätt valda exempel från litteraturen kunde tolkas utifrån hur begreppen konsekvensetik, avsiktsetik, pliktetik och diskursetik beskrivits i övrig kurslitteratur (se Edlund, 20IO; Henriksen \& Vetlesen, 20I3). I relation till exempelvis avsiktsetik, som i kurslitteraturen beskrivs som ett uttryck för att en handling ska förstås som god om avsikten med handlandet är gott (Edlund, 20IO; Henriksen \& Vetlesen, 20I3), menade studenterna att det går att förstå de situationer som beskrivs i boken utifrån hur man, vid den tiden, såg på vad som skulle definieras som goda avsikter. Det förekom i studentgrupperna att man diskuterade hur tillgång till vård möjliggjordes också för personer vilka inte hade förutsättningar att själva finansiera behandling och läkemedel och att det, vid denna tid, sågs som ett uttryck för god vilja och stöd att erbjuda mindre bemedlade att ingå i behandlingsprogram utan kostnad, men med en förväntan om att patienter skulle ställa upp på att bidra till medicinsk forskning och utveckling. Ett annat exempel är hur studenterna, med stöd av hur pliktetik definieras i kurslitteraturen, diskuterade hur läkarens beslut att utan samtycke ta vävnadsprov från Henrietta kunde förstås som ett uttryck för upplevd plikt hos läkaren. Pliktetik beskriver att vad som ska bedömas som etiskt riktigt styrs av vad som uppfattas som en plikt, det vill säga någonting som upplevs vara en ofrånkomlig förväntan vad gäller handlande (Henriksen \& Vetlesen, 2013; Edlund, 20IO). Sådana tolkningar kunde till exempel knytas till den forskningsintensiva miljö i vilken läkaren ingick och hur det, utifrån det sammanhang som beskrivs i biografin, kan förstås som en miljö där den medicinska forskningens utveckling prioriteras framför enskilda patienters eventuella samtycke till vävnadsprov. I "Den odödliga Henrietta Lacks" illustreras också hur provtagning, på företrädesvis svarta patienter med låg utbildning och bristande ekonomiska förutsättningar, på bred front användes inom forskning och utveckling. De vävnadsprover som togs från Henrietta Lacks var således ett i raden av cellprover som togs från personer från denna patientgrupp vid denna tid.

Vår bedömning var att studenterna i de flesta grupper lyckades väl vad gäller att knyta kursens teorier och etiska perspektiv till den berättelse som utgör grunden för biografin genom fokus på valda scener. I vissa grupper kom samtalen stundvis att fastna i delar av boken som väckt särskilt starka känslor men som i lägre grad lämpar sig för tolkning baserad på olika etiska utgångspunkter, men inte i någon grupp blev dessa samtal allt för omfattande. Sådana samtal kunde till exempel utgöras av hetsiga diskussioner baserade på negativa bedömningar av hur 
ansvarig läkare uppfattades som person. Det förekom exempel på hur scener ur biografin väckte frågor om situationer vilka studenterna mött i sina egna vardagsliv. Det kunde till exempel handla om (makt)relationen mellan läkare och patient och/eller upplevd utsatthet vid gynekologiska undersökningar. Sådana associationer, vilka endast tog en mindre plats i samtalen, visade att studenterna relaterade innehållet $\mathrm{i}$ biografin till en svensk kontext och vår egen tid.

Diskussionerna i grupperna knöts till såväl innehållet i biografin som till teoretiska perspektiv och berörde individ-, grupp- och samhällsnivå. På individnivå kunde till exempel ansvarig läkares val att inte fråga Henrietta om samtycke inför vävnadsprov för forskningsändamål diskuteras. I några fall diskuterades huruvida detta kunde förstås som etiskt försvarbart utifrån ett utilitaristiskt perspektiv på individnivå, eftersom det utilitaristiska perspektivet ger att ett handlande utgår ifrån störst nytta åt så många människor som möjligt (Henriksen \& Vetlesen, 2013). Den enskilda individens lidande (Henrietta) ställs då mot en stor mängd personers nytta (alla de som erbjudits lyckosam behandling till följd av forskning baserad på HeLa-celler). På gruppnivå diskuterades exempelvis det faktum att Henrietta var svart och hur tillgång till vård i det sammanhang där hon befann sig tydligt hängde ihop med etnicitet och socioekonomisk status. Utifrån detta reflekterade studenterna över hur mörkhyade erbjöds kostnadsfri vård i utbyte mot att ingå i olika typer av studier, något som i biografin beskrivs som vanligt förfarande vid denna tid. I dessa diskussioner funderade studenterna över de etiska problem som följer av förväntan om att mörkhyade personer med låg socioekonomisk status ska ställa upp på att delta i forskning och, å andra sidan, de goda avsikter som samtidigt fanns i fråga om att erbjuda vård till en grupp människor som annars skulle ställas helt utanför systemet. Reflektioner på samhällsnivå handlade ofta om den forskning och utveckling som följt baserat på de celler som tagits från Henrietta Lacks där den enskilda individens utsatthet ställs mot enorm utveckling av den medicinska forskningen. Denna typ av brytningar, mellan "å ena sidan" och "å andra sidan" visade hur enskilda händelseförlopp kan tolkas på olika sätt beroende på vems perspektiv som antas och vilket etiskt perspektiv som ligger till grund för tolkningar som görs.

Studenterna diskuterade också skiljelinjer mellan å ena sidan moraliskt/omoraliskt handlande och å andra sidan teoretiska tolkningar på etiskt handlande. Att ansvarig läkare, utan informerat samtycke, tog celler från Henrietta och därefter spred dem vidare, kan å ena sidan ses som moraliskt förkastligt utifrån Henriettas och hennes anhörigas/efterlevandes perspektiv, å andra sidan som moraliskt försvarbart med tanke på den stora betydelse HeLa-cellerna haft för medicinsk forskning. Här diskuterade studenterna alltså att något som de spontant uppfattade som omoraliskt ändå kunde försvaras som etiskt riktigt, utifrån något eller några av de teoretiska perspektiv de arbetat med i kursen. I dessa resonemang, där olika teoretiska perspektiv ställs mot varandra och där situationer tolkas utifrån olika nivåer (individ, grupp, samhälle) övades studenternas förmåga till kritiskt tänkande, alltså att observera, ge uttryck för och problematisera sina egna synsätt (Wolrath Söderberg, 20I6) baserat på kunskap om teoretiska perspektiv och applicerat på de dilemman som skildras hämtade från biografin.

En utmaning relaterad till boken som sådan var dess komplexa innehåll. Biografin konfronterar studenterna med utmanande frågeställningar i fråga om etik. Berättelsen om Henrietta Lacks ställer inte bara frågor kring medicinsk etik och forskningsetik, utan också om etik och moral relaterat till frågor rörande makt och privilegier utifrån etnicitet, utbildning och socioekonomisk status. Dessa komplexa frågor ska dessutom förstås i relation till det historiska och kulturella sammanhang i vilket Henrietta levde. Den bedömning som vi lärare gjorde utifrån att lyssna på samtalen var att studenterna lyckades väl med att, å ena sidan, tolka situationen utifrån de villkor som ramar in Henriettas livsberättelse och att, å andra sidan, överföra dessa 
diskussioner till frågor av etisk karaktär med relevans i nutidens Sverige. Det innebär exempelvis att frågor om etik i mötet mellan vårdpersonal och patient diskuterades utifrån hur det ser ut idag och att frågan om informerat samtycke diskuterades utifrån hur dessa frågor kan förstås idag. I vissa fall kom dessa frågor att leda till aha-upplevelser hos studenter vad gäller förståelsen för hur komplexa dessa frågor ännu är och att det också idag kvarstår många etiska dilemman och situationer som är svåra att lösa.

Vad vi som lärare har kunnat se är alltså att de situationer och händelseförlopp som beskrivs i "Den odödliga Henrietta Lacks" framstår som såväl engagerande som mångbottnade när studenterna talar om dem. Studenterna kan tolka samma enskilda situation, till exempel det faktum att ansvarig läkare tog cellprover för forskning från Henrietta utan samtycke, utifrån olika (teoretiska) perspektiv och med olika utgångspunkter med individen, gruppen, organisationen och/eller samhället i centrum för de tolkningar som görs. I tidigare forskning har det visat sig att studenter som läst biografin utvecklats vad gäller hantering av frågor om etiska dilemman (Malcom, 20I8) vilket känns igen också i föreliggande undervisningsexempel. Erfarenheterna av det seminarium som genomförts här visar också hur tolkningar knyts till det specifika sammanhang i vilket Henrietta levde. På liknande sätt, som synliggjorts i tidigare studier (Hunt et al, 2020; Virtue et al., 20I8), relateras de etiska frågor som synliggörs genom biografin till betydelsen av kulturellt sammanhang och socioekonomisk status. Genom samtal i grupp om livsberättelsen om Henrietta har studenterna förmått koppla ihop frågor om etik och hälsa, vilket också det känns igen från tidigare forskning där användningen av "Den odödliga Henrietta Lacks" diskuterats (jämför med Black et al., 20I2; Bridges \& Hanson, 20I2; Malcom, 2018).

\section{Studenternas synpunkter}

Studenternas perspektiv på kursens genomförande är hämtat från den kursvärdering som genomfördes efter avslutad kurs (juni 2020). Mittuniversitetet använder sig av en digital lösning där kursvärderingarna är utformade på ett sådant sätt att de kan bidra med återkoppling relaterad till studenternas uppfattning om sitt eget lärande (Erikson, Erikson \& Punzi, 20ı6), förbättring av kursens pedagogiska upplägg och att möta behovet av systematisk kvalitetssäkring på institutionell nivå (Spooren, Brockx \& Mortelmans, 2013) och att ge studenterna möjlighet att påverka den egna utbildningen (Astin, 1999). Kursvärderingen för Etikkursen bestod av slutna frågor med förutbestämda svarsalternativ på en femgradig likertskala ( $\mathrm{I}=$ mycket dåligt, $5=$ mycket bra), varav fyra var specifikt utformade i relation till användningen av biografin, samt några öppna frågor om lärande och utveckling.

Studenternas (5I studenter inskrivna på kursen, svarsfrekvens 49\%) helhetsintryck av kursen var mycket gott $(4,5)$. Studenterna var också generellt sett nöjda med användningen av "Den odödliga Henrietta Lacks" $(4,5)$. Detta bekräftas av svar på den öppna frågan om vad som bidragit till lärande, där det nämns att användningen av biografin varit ett "bra inslag" och att det gav "många nya synpunkter". En av studenterna uttrycker det så här:

Bra med ["Den odödliga Henrietta Lacks"] som lärmaterial. Man tänkte till ordentligt när man läste och fick många nya synpunkter på allt $i$ och med att man redan läst lite om [de teoretiska] perspektiven.

En annan student ger uttryck för hur användningen av biografin engagerat och upplevts som ett intressant inslag i Etikkursen: 


\section{Erika Wall}

Jag tycker att det har varit ett väldigt bra inslag med boken om Henrietta Lacks. En väldigt intressant bok ur etiska perspektiv och den gjorde kursen väldigt intressant upplevde jag.

Den specifika frågan kring litteraturseminariet får också ett högt värde $(4,3)$ vilket följs av positiv återkoppling som svar på de öppna frågorna där "seminarium", "samtal" och "diskussion" återkommer ifråga om vad i det pedagogiska upplägget som upplevts vara till stöd för lärande. Det uppfattades också från studenthåll som att litteraturseminariet fungerade väl som del av helheten för kursen: "Kursen kändes genomtänkt i att vi fick arbeta själva och tillsammans samt diskuteras i större grupp." En av studenterna återknöt specifikt till den seminarieuppgift som fokuseras här genom att lyfta fram dess betydelse för ökad förståelse och kritiskt tänkande genom reflekterande samtal:

Seminarium gör att vi har kunnat diskutera och arbeta runt det etiska problem vi ska förstå.

Den kritik som framförs i kursvärderingen är avgränsad till behov av "mer tid för diskussion". Ett förslag som framkommer är att dela upp seminarieuppgiftens båda delar: "Men det skulle kunna vara två tillfällen t.ex. med någon dag emellan" och ett annat konkret förslag är att genomföra seminarierna i något större grupper "för att få en mer mångsidig diskussion".

\section{LEVANDE SAMTAL?}

De reflektioner som redovisats här ger en bild av att upplägget med en biografi som grund för seminariebehandling bidragit till lärande om etiska perspektiv inom rehabiliteringsvetenskap. Den samlade bedömningen vad gäller om, och hur, användningen av en biografi kan bidra till reflekterande diskussioner inom ramen för samhällsvetenskaplig grundutbildning, baserat på erfarenheter utifrån ett lärarperspektiv och studenternas återkoppling, är att den valda biografin - "Den odödliga Henrietta Lacks" - lämpade sig väl till det. Studenterna gavs möjlighet att knyta teoretiska perspektiv till en specifik berättelse som är möjlig att tolka utifrån varierade utgångspunkter.

Det underlag som använts här, egna erfarenheter som lärare och studenternas perspektiv genom en kursvärdering, ger dock ingen mätbar information om i vilken mån användningen av biografin bidragit till ökad kunskap och/eller fördjupad förståelse för etiska perspektiv. Också med annat metodologiskt upplägg hade det varit svårt att uttala sig om effekterna av användning av en biografi som stöd för reflekterande diskussioner då tidigare forskning visat att det är svårt att nå mätbara effekter av bokklubbsliknande aktiviteter i högre utbildning (Macnaughton, 2000; Middleton, Sen \& Middleton, 1995). Trots metodologiska reservationer är den samlade bedömningen här att "Den odödliga Henrietta Lacks" tycks inspirera till analytiska resonemang kring etik. Dessa resultat går tolka som ett uttryck för att boken bidrar till lärande genom att aktiva och engagerade studenter har en bättre lärandeprocess (Biggs, 2003). Resultaten bekräftar också tidigare forskning där biografin bedömdes bidra med förståelse för sociala determinanter för hälsa på ett sätt som klassisk kurslitteratur inte bedömdes kunna göra (Dimaano \& Spigner, 20I7). På samma sätt är slutsatsen här att boken fungerar väl som grund för reflekterande diskussioner baserade på olika teoretiska perspektiv på etik. Användningen av en biografi har således bedömts bidra till reflekterande diskussioner, men det finns också behov av ytterligare utveckling av kursen. Utifrån ett lärarperspektiv är bedömningen att de samtal som uppstod genom litteraturseminariet är så centrala för lärande 
att ytterligare förutsättningar för reflektiva samtal behöver skapas. Detta ansluter också till de förslag till förändringar som framkommit av kursvärderingen. Det är tydligt att vad som önskas från studenterna inte är något annat, utan mer av det befintliga. Mot denna bakgrund ges seminarieformen större utrymme vid genomförandet av kursen våren 202I och mer tid avsätts specifikt för det litteraturseminarium som diskuteras här. Att ge utrymme för studenter att diskutera svåra frågor tillsammans kan också ses som ett svar på den kritik som framförts vad gäller att studenter allt för ofta lämnas ensamma med sina tolkningar inom ramen för högre utbildning. Textläsningar är något som lyfts fram som särskilt viktigt att göra tillsammans (Dodillet, 2015).

\section{Levnadsöden i biografier och fiktion till stöd för reflekterande samtal}

Jämfört med patientfall som ofta används i undervisning om etik inom medicinska utbildningar återges i biografin ett specifikt levnadsöde. Biografin kontextualiserar livsberättelsen som sätts i en historisk kontext och presenteras i en sammanhållen berättelse, ett narrativ. Biografins autenticitet och komplexitet ger liv åt en specifik person och har här visat sig främja studenternas engagemang och ge bra underlag för reflekterande samtal. Utifrån de likheter berättandet i en sådan biografi har med andra narrativa texter kan man också tänka sig att andra typer av texter utan koppling till verkliga händelser kan fungera lika väl som underlag för reflektion kring etiska frågor. I tidigare studier har det visat sig att skönlitteratur särskilt kan bidra vad gäller att överföra abstrakta teoretiska fenomen till greppbara berättelser som utspelar sig i vardagliga sammanhang (Dimaano \& Spinger, 2017; Lewenstein, 2007; Lie et al., 2002; Nisbet \& Fahy, 20I3; Walton, 20I4). Baserat på de erfarenheter som gjorts här kan man därför tänka sig att även fiktion kan bidra till reflekterande samtal i olika typer av kurser kring fenomen vilka är svåra att närma sig genom traditionell kurslitteratur.

Intresset för att använda icke-traditionell kurslitteratur har funnits en längre tid inom rehabiliteringsvetenskap vid Mittuniversitetet. I samband med att biografin, "Den odödliga Henrietta Lacks", föreslogs som obligatorisk kurslitteratur i en kurs fick diskussionen om icke-traditionell litteratur i undervisningen förnyad kraft. Detta ledde fram till att ämneskollegiet, i samverkan med en representant från lärosätets Forsknings- och utbildningsstöd, inledde ett internt arbete kring fiktion i undervisning. Under 2020 har en mindre grupp (5-7 deltagare, alla verksamma som lärare i rehabiliteringsvetenskap) läst skönlitteratur och träffats för diskussion kring böckernas eventuella användbarhet inom ramen för utbildning på grund- och avancerad nivå. Diskussioner pågår också om huruvida det går att skapa förutsättningar att sprida detta arbete inom ramen för hela universitetet. Detta visar att en mindre förändring på en enskild kurs kan bidra till intresse för utveckling $i$ andra kurser också utanför den egna institutionen. Förhoppningen är att föreliggande reflektion ska bidra till ytterligare ringar på vattnet genom att väcka tankar hos universitetslärare runt om i landet kring betydelsen av icke-traditionell kurslitteratur till stöd för reflekterande samtal.

\section{FÖRFATTARPRESENTATION}

Erika Wall är docent i sociologi, universitetslektor i rehabiliteringsvetenskap och meriterad lärare vid institutionen för hälsovetenskap, Mittuniversitetet. Hennes undervisning fokuseras kring teoretiska och praktiska perspektiv på etik i arbetsliv och rehabilitering samt på processer för att stärka studenters vetenskapliga skrivande. Hennes forskning utgår ifrån hälsofrämjande perspektiv och fokuserar på upplevelser av risk och trygghet i arbetslivet. 


\section{Erika Wall}

\section{REFERENSER}

Astin, A. W. (1999). Student involvement: A developmental theory for higher education. Journal of College Student Development, 40(5), 518-529.

Biggs, J. (1999). What the student does: teaching for enhanced learning. Higher Education Research \& Development, 18(1), 57-75. https://doi.org/10.1080/0729436990180105

Biggs, J. (2003). Aligning teaching and assessing to course objectives. Teaching and Learning in Higher Education: New Trends and Innovations, 2, 13-17.

Biggs, J. \& Tang, C. S. (2011). Teaching for quality learning at university: what the student does. Maidenhead: Open University Press.

Black, E. P., Policastri, A., Garces, H., Gokun, Y. \& Romanelli, F. (2012). A pilot common readning experience to integrate basic and clinical sciences in pharacy education. American Journal of Pharmaceutical Education, 76(2), Article 25. https://doi.org/10.5688/ajpe76225

Bridges, D. R. \& Hanson, M. (2012). Mapping and integrating online interprofessional teaching strategies to achieve interprofessional student competencies. Health and Interprofessional Practice, 1(3), eP130. https://doi.org/10.7772/2159-1253.1030

Clouser, K. D. (1990). Humanities in medical education: some contributions. The Journal of medicine and philosophy, 15(3), 289-301. https://doi.org/10.1093/jmp/15.3.289

Dimaano, C. \& Spigner, C. (2017). Teaching from The Immortal Life of Henrietta Lacks: Student perspectives on health disparities and mecial ethics. Health Education Journal, 76(3), 259-270. https://doi.org/10.1177/0017896916667624

Dodillet, S. (2015). När kurslitteratur blir receptförslag - Om bristen på kritiska textläsningar. Högre utbildning, 5(2), 139-140. Hämtad från https://hogreutbildning.se/index.php/hu/article/view/773

Eckart, M. \& Fjordevik, A. (2015). Könsmedveten litteratur som ett led i jämställdhetsarbetet. Högre utbildning, 5(2), 127-131. Hämtad från https://hogreutbildning.se/index.php/hu/article/view/771

Edlund, L. (2010). Etik i arbetslivet. En träningsbok för chefer och medarbetare. Stockholm: Liber.

Erikson, M., Erikson, M. G. \& Punzi, E. (2016). Student responses to a reflexive course evaluation. Reflective Practice, 17(6), 663-675. https://doi.org/10.1080/14623943.2016.120687

Fjellström, M. \& Wester, M. (2019). Universitetslärares skrivande om och för sin undervisning. Drivkrafter, stöd och utmaningar. Högre utbildning, 9(1), 20-33. https://doi.org/10.23865/hu.v9.1063

Henriksen, J- O. \& Vetlesen, A. J. (2013). Etik i arbete med människor. Lund: Studentlitteratur.

Hunt, L., Tkach, N., Kaushansky, L. \& Benz Scott, L. (2020). Analysis of an Interprofessional Experiental Learning Program Utilizing the Case of Henrietta Lacks. Pedagogy in Health Promotion, 6(3), 203-2011. https://doi.org/10.1177/2373379919875750

Lewenstein, B. V. (2007). Why should we care about science books? Journal of Science Communication, 6(1), 1-7. https://doi.org/10.22323/2.06010303

Lewis, C. L. \& Estis, J. M. (2020). Using Team-Based Learning to Teach Human Subjects Research Ethics. Medical Science Educator, 30, 617-620. https://doi.org/10.1007/s40670-019-00846-7

Lie, D., Rucker, L. \& Cohn, F. (2002) Using literature as the framework for a new course. Academic Medicine, $77(11), 1170$.

Macnaughton, J. (2000). The humanities in medical education: context, outcomes and structures. Medical Humanities, 26(1), 23-30. https://doi.org/10.1136/mh.26.1.23

Malcom, D. R. (2018). Teaching and assessing clinical ethics through group reading experience and student-led discussion. Currents in Pharmacy Teaching and Learning, 10, 602-610. https://doi. org/10.1016/j.cptl.2018.01.009

Middleton, J. A., Sen, P., \& Middleton, J. R. (1995). Literature and medicine: contributions to clinical practice. Annals of internal medicine, 123(12), 965-966. https://doi.org/10.7326/0003-4819-12312-199512150-00028

Nisbet, M. C. \& Fahy, D. (2013). Bioethics in popular science: Evaluating the media impact of The Immortal Life of Henrietta Lacks on the biobank debate. BMC Medical Ethics, 14(1), 10. https://doi. org/10.1186/1472-6939-14-10 
Silén, C. \& Bolander Laksov, K. (2013). Att skapa pedagogiska möten i medicin och vård. Lund: Studentlitteratur. Skloot, R. (2010). The immortal life of Henrietta Lacks. New York, NY: Crown.

Skloot, R. (2012). Den odödliga Henrietta Lacks. Stockholm: Leopard förlag.

Spooren, P., Brockx, B. \& Mortelmans, D. (2013). On the Validity of Student Evaluation of Teaching:

The State of the Art. Review of Educational Reserach, 83(4), 598-642. https://doi.org/10.3102/ 0034654313496870

Van Winkle, L. J., Bjork, B. C., Chandar, N., Cornell, S., Fjortoft, N., Green, J. M., La Salle, S., Lynch, S. M., Viselli, S. M. \& Burdick, P. (2012). Interprofessional Workshop to Improve Mutal Understanding Between Pharmacy and Medical Students. American Journal of Pharmaceutical Education, 76(8), Article 150. https://doi.org/10.5688/ajpe768150

Virtue, E., Wells, G., MacKusick, C., Murphy-Nugen, A. \& Rose, A. (2018). The Immortal Life of Henrietta Lacks: Using a Common Read to Transform a Learning Community. Learning Communities Reserach and Practice, 6(1), Article 4.

Walton, K. L. W. (2014). Using a popular science nonfiction book to introduce biomedical research ethnics in a biology majors course. Journal of Microbiology and Biology Education, 15(2), 240-242. https://doi.org/10.1128/jmbe.v15i2.767

Weed, D. L. (1995). Epidemiology, the humanities, and public health. American Journal of Public Health, 85(7), 914-918.

Wolrath Söderberg, M. (2016). Att få ihop teorier, praktik och kritiskt tänkande i seminariet - ett topiskt förslag. Högre utbildning, 6(1), 31-49.

Ödman, P- J. (2007). Tolkning, forståelse, vetande. Hermeneutik i teori och praktik. Stockholm: Norstedts. 